\title{
KARAKTERISTIK PENGGUNA DAN APLIKASI PADA TINGKAT PENGGUNAAN (STICKINESS) APLIKASI VIDEO PENDEK XYZ
}

\author{
USER AND APPLICATION CHARACTERISTICS AT XYZ SHORT VIDEO APPLICATION STICKINESS
}

\author{
Gagan Gandara*), Ujang Sumarwan $^{* *}$, dan Sufrin Hannan $\left.{ }^{* * *}\right)$ \\ *) Sekolah Bisnis, IPB University \\ Jl Pajajaran Bogor, 16151, Indonesia \\ ${ }^{* *}$ Departemen Ilmu Keluarga dan Konsumen, Fakultas Ekologi Manusia, IPB University \\ Gedung GMSK Lantai 2, Kampus IPB Darmaga Bogor 16680, Indonesia \\ ${ }^{* * *)}$ Sekolah Pascasarjana, Universitas Pakuan \\ Jl. Pakuan PO Box 452 Bogor 16143, Indonesia
}

\begin{abstract}
This study aimed to analyze differences in user characteristics (demographics and motivation) and the XYZ application characteristics (content category and service quality) at the level of use (stickiness). This study's respondents were 797 daily users, consisting of 584 uploaders (have uploaded videos) and 213 watchers (never uploaded videos). The data processing methods used were descriptive analysis and Kruskal Wallis and Mann Whitney U difference test. The results showed that the users were mostly male, aged 18-30 years, had a high school education level and income below 2 million rupiahs per month. The motivations for sharing videos were mostly to make money, share with friends and family, and gain followers. The most preferred content categories by watchers were good looking women, comedy, and scenery. Watchers were satisfied with the existing content category. Uploaders had a neutral preference for service quality. Accumulatively, $90.8 \%$ of all respondents used the application for 10-30 minutes or more daily. The motivation to share videos, the most preferred content category, the quality of service, namely the ease of recording videos, and the completeness and suitability of the music catalog were significantly different at the level of use. Managerial implications are addressed in terms of content development, enhancement of all aspects of service quality, and promotion strategies to improve XYZ application performance.
\end{abstract}

Keywords: content category, demographics, motivation, service quality, stickiness

\begin{abstract}
Abstrak: Penelitian ini bertujuan menganalisa perbedaan karakteristik pengguna (demografi dan motivasi) serta karakteristik aplikasi XYZ (kategori konten dan kualitas layanan) pada tingkat penggunaan (stickiness). Sebanyak 797 pengguna harian, terdiri dari 584 uploader (sudah pernah unggah video) dan 213 watcher (belum pernah unggah video) menjadi responden penelitian ini. Pengolahan data menggunakan analisis deskritif, uji beda Kruskal Wallis dan Mann Whitney U. Hasil penelitian menunjukkan bahwa, pengguna sebagian besar laki-laki, usia 18-30 tahun, tingkat pendidikan sekolah menengah atas, serta pendapatan di bawah 2 juta rupiah setiap bulan. Motivasi berbagi video sebagian besar untuk menghasilkan uang, berbagi dengan teman dan keluarga serta untuk mendapatkan pengikut. Kategori konten yang paling disukai oleh watcher adalah wanita berpenampilan menarik, komedi, dan pemandangan. Watcher puas dengan kategori konten yang ada. Uploader memiliki preferensi netral terhadap kualitas layanan. Secara akumulatif, 90,8\% dari seluruh responden menggunakan aplikasi $10-30$ menit atau lebih, setiap harinya. Motivasi membagikan video, kategori konten yang paling disukai, kualitas layanan yaitu kemudahan untuk merekam video serta kelengkapan dan kesesuaian katalog musik berbeda nyata pada tingkat penggunaan. Implikasi manajerial ditujukan dalam hal pengembangan konten, peningkatan seluruh aspek kualitas layanan, serta strategi promosi untuk peningkatan kinerja aplikasi XYZ.
\end{abstract}

Kata kunci: demografi, kategori konten, kualitas layanan, motivasi, stickiness

\footnotetext{
${ }^{1}$ Corresponding author:

Email: gagan.gandara@ganadvertising.com
} 


\section{PENDAHULUAN}

Dewasa ini layanan video pendek telah menjadi fitur utama pada aplikasi sosial media seperti; Twitter, Facebook, Instagram, dan Snapchat. Aplikasi khusus sosial media berbasis video pendek pun bermunculan, seperti Tiktok dan aplikasi XYZ. Video pendek menjadi tren disebabkan oleh pengalaman visual yang dominan, rentang perhatian manusia yang semakin pendek serta keinginan menyampaikan inti pesan secara langsung. Didukung dengan potensi pasar yang besar, terdapat 171,2 juta pengguna internet di Indonesia (APJII, 2019), menyebabkan banyak aplikasi video pendek masuk ke Indonesia, termasuk salah satunya adalah aplikasi video pendek XYZ. Aplikasi video pendek XYZ adalah aplikasi yang berasal dari Tiongkok, memiliki jumlah pengguna aktif bulanan mencapai 316 juta, dengan total jumlah video sebanyak 20 miliar video. Menghasilkan pendapatan sebesar 7,1 Miliar Dolar Amerika pada tahun 2019, yang menempati posisi tertinggi di pasar Tiongkok (China Internet Watch, 2020). Adapun aplikasi sosial media lainnya seperti Facebook saat ini memiliki pengguna aktif bulanan mencapai 2,45 miliar, disusul Youtube mencapai 2 miliar, Instagram mencapai 1 miliar, Tiktok mencapai 800 juta, Snapchat mencapai 382 juta, dan Twitter mencapai 340 juta pengguna (Kemp, 2020).

Permasalahan utama dalam bisnis aplikasi di Indonesia adalah masih rendahnya tingkat retensi penggunaan (retention rate) maupun stickiness, begitupun yang terjadi pada aplikasi XYZ. Retention rate adalah persentase jumlah pengguna yang mengunjungi dan kembali menggunakan aplikasi pada hari berikutnya. Sedangkan stickiness adalah intensitas menggunakan aplikasi yang ditunjukan dengan frekuensi dan durasi serta keberlanjutan dalam menggunakan aplikasi (Hsu dan Tang, 2019). Stickiness menjadi sangat penting, karena berhubungan dengan tingkat monetisasi suatu aplikasi. Sehingga penting untuk mengetahui faktorfaktor apa saja yang berhubungan dengan tingkat stickiness aplikasi XYZ di Indonesia, terutama yang berhubungan dengan karakteristik pengguna maupun karakteristik aplikasi itu sendiri.

Hasil penelitian sebelumnya mengungkapkan bahwa karakteristik pengguna aplikasi mempengaruhi tingkat stickiness, diantaranya adalah jenis kelamin dan motivasi. Laki-laki lebih kecanduan media sosial daripada perempuan (Alnjadat et al. 2019). Penelitian lain mengungkapkan bahwa laki-laki cenderung mencari kepuasan dalam bentuk "like" dan "comment" serta mendapatkan "popularitas" yang lebih tinggi dibandingkan dengan wanita (Dhir dan Torsheim, 2016). Ada perbedaan antara remaja laki-laki dan wanita dalam hal mendefinisikan dan bereaksi terhadap seks dalam konten iklan. Laki-laki menunjukkan preferensi gairah seksual yang lebih tinggi terhadap video klip dengan stimulus visual fisik, sedangkan wanita lebih suka stimulus dengan alur cerita dan suasana hati (Chung et al. 2013). Penelitian mengenai hubungan motivasi dengan stickiness pada empat tipe sosial media; Facebook, Twitter, Instagram dan Snapchat menunjukan bahwa motivasi hiburan dan kenyamanan merupakan motivasi utama yang berpengaruh terhadap intensitas penggunaan aplikasi (Alhabash dan Ma, 2017). Prediktor terkuat untuk menyukai dan tidak menyukai video di Youtube adalah motif hiburan yang menenangkan; komentar dan pengunggahan sangat diprediksi oleh motif interaksi sosial; berbagi sangat diprediksi oleh motif pemberian informasi (Khan, 2016).

Stickiness juga dipengaruhi oleh karakteristik aplikasi, seperti; kualitas layanan (Lien et al. 2017), kelengkapan dan keberagaman produk dan fitur, insentif/hadiah, kenyamanan digunakan (Matemba et al. 2018), persepsi fungsi/kegunaan (Kim et al. 2016), persepsi kemudahan (Fang dan Fang, 2016), keaslian konten (Xu et al. 2018), informatif, personal, serta digunakan oleh banyak orang (Kim et al. 2016). Ketersediaan konten yang lengkap, kegunaan dan kemudahan yang dirasakan, mempengaruhi secara positif kesediaan untuk berlangganan (Hasan, 2017). Kualitas video secara signifikan mempengaruhi citra kognitif dan afektif dari isi video yang ditonton, dan interaksi yang dirasakan secara signifikan mempengaruhi perilaku penonton (Li, 2019).

Dimensi kualitas layanan yaitu; kegunaan, mudah digunakan, hiburan, hubungan komplementer, pelayanan pelanggan, dan interaksi pembeli-penjual berpengaruh sangat signifikan terhadap kepuasan pelanggan (Manalu et al. 2007). Kualitas informasi, kualitas sistem, dan kualitas layanan berpengaruh positif terhadap kepuasan pengguna aplikasi e-learning (Rahmat et al. 2019). Memperkuat hubungan dengan pelanggan dalam menciptakan kepuasan, sangat dipengaruhi oleh keseluruhan layanan yang disiapkan yang memperhatikan aspek-aspek yang diharapkan, dirasakan pelanggan, atau yang diterimanya dari jasa yang diterima oleh pelanggan (Hannan, 2014). Kualitas 
layanan memiliki hubungan yang kuat dengan perilaku konsumsi masa depan dalam konteks niat pelanggan untuk mengunjungi, membeli, dan merekomendasikan toko kepada orang lain (Khudri dan Sultana, 2015). Layanan pelanggan, privasi dan hedonisme membentuk kepuasan yang selanjutnya pembentuk kesetiaan pelanggan (Ahmad et al. 2017). Ada perbedaan yang signifikan antara laki-laki dan wanita dalam peringkat kualitas layanan. Kualitas layanan lebih penting bagi wanita dibandingkan dengan laki-laki. Ada perbedaan yang signifikan antara kelompok pendapatan yang berbeda dalam persepsi kualitas layanan (Jelcic, 2015). Adapun tujuan yang ingin dicapai dalam penelitian ini adalah 1) menganalisis karakteristik pengguna yaitu demografi dan motivasi, serta karakteristik aplikasi XYZ berupa kategori konten dan kualitas layanan; 2) menganalisis intensitas penggunaan aplikasi XYZ; 3) menganalisis hubungan karakteristik pengguna dan karakteristik aplikasi terhadap tingkat penggunaan.

\section{METODE PENELITIAN}

Penelitian ini dilakukan mulai bulan Juli 2019 sampai dengan bulan Februari 2020. Data yang digunakan adalah data primer hasil survei terhadap pengguna aktif aplikasi XYZ. Kuesioner secara daring disebarkan melalui pesan langsung secara bersamaan melalui CMS (content management system) kepada semua pengguna aktif aplikasi XYZ selama bulan Juli 2018. Sebanyak 1000 data contoh diambil dengan teknik urutan pembangkitan bilangan acak. 1000 data contoh diambil mempertimbangkan proses penyaringan data yang akan dilakukan selanjutnya, sehingga jumlah contoh pada akhirnya sama atau lebih besar dari jumlah contoh pada nilai peluang maksimal menurut rumus:

$$
\mathrm{n}=\left(\left[\mathrm{z}_{\alpha / 2}\right]^{2} \hat{\mathrm{p}} \cdot \hat{\mathrm{q}}\right) / \mathrm{E}^{2}
$$

Keterangan: n (Jumlah sampel), E (derajat kesalahan), nilai $\mathrm{Z}$ pada tingkat kepercayaan $\alpha / 2$ dan peluang maksimum pada $\widehat{\mathrm{P}}=0,5$ dan $\widehat{\mathrm{q}}=0,5$ (Triola, 1992). Sehingga pada tingkat kepercayaan 95\%, $\alpha=0,05, \mathrm{E}=$ $5 \%$, jumlah data contoh akhir minimal $\mathrm{n}=208$. Kemudian data contoh disaring berdasarkan kelengkapan data dan kriteria pengguna harian, sehingga didapatkan 797 data contoh. Selanjutnya data dikategorikan menjadi uploader (584 data contoh) dan watcher (213 data contoh). Sehingga data contoh terkecil dalam hal ini kategori watcher tidak lebih kecil dari nilai data contoh minimal $\mathrm{n}=208$.
Variabel penelitian terdiri dari empat variabel bebas antara lain adalah demografi, motivasi, kategori konten dan kualitas layanan, dan satu variabel terikat yaitu tingkat penggunaan aplikasi XYZ (stickiness) (Tabel1). Skala pengukuran untuk variabel demografi, motivasi dan kategori konten menggunakan skala nominal dan ordinal. Adapun untuk variabel kualitas layanan diukur dengan skala Likert pada skala 1 sampai dengan 5, yang menjelaskan tingkat kepuasan pengguna dari sangat tidak puas (skala 1), tidak puas (skala 2), netral (skala 3), puas (skala 4) dan sangat puas (skala 5). Adapun stickiness diukur dengan skala interval.

Pengolahan data menggunakan analisis deskriptif kualitatif. Analisis kuantitatif digunakan untuk variabel kualitas layanan, terdiri dari uji normalitas, transformasi data skala interval dengan metode $\mathrm{Z}$ skor, uji validitas dan uji reliabillitas. Pengujian hubungan antar variabel dan antar kelompok variabel menggunakan analisis uji beda Kruskal Wallis (lebih dari dua kelompok variabel) dan Mann Whitney U (dua kelompok variabel).

Demografi, motivasi, kategori konten dan kualitas layanan berhubungan dengan perilaku pengguna dalam tingkat penggunaan aplikasi XYZ. Hal ini didasarkan bahwa proses pengambilan keputusan konsumen dipengaruhi oleh faktor individu, faktor lingkungan dan strategi pemasaran (Sumarwan, 2011). Faktor individu dalam hal ini adalah demografi dan motivasi, serta hubungan antara demografi dan motivasi. Adapun faktor lingkungan dalam hal ini adalah kategori konten dan kualitas layanan. Pengguna dalam penelitian ini dibagi dalam dua kelompok, yaitu uploader dan watcher. Uploader merupakan pengguna yang sudah pernah mengunggah video. Adapun watcher adalah pengguna yang belum pernah mengunggah video. Pada penelitian ini uploader mengukur persepsi kualitas layanan. Adapun watcher mengukur persepsi kategori konten.

Hipotesis yang dikembangkan dalam penelitian ini (Gambar 1) adalah 1) $\mathrm{H}_{1}$ : Adakah perbedaan dari dua atau lebih kelompok variabel demografi pada stickiness. 2) $\mathrm{H}_{2}$ : Adakah perbedaan dari dua atau lebih kelompok variabel motivasi pada stickiness. 3) $\mathrm{H}_{3}$ : Adakah perbedaan dari dua atau lebih kelompok variabel kategori konten pada stickiness. 4) $\mathrm{H}_{4}$ : Adakah perbedaan dari dua atau lebih kelompok variabel kualitas layanan pada stickiness. 
Tabel 1. Variabel penelitian

\begin{tabular}{|c|c|c|c|}
\hline Variabel & Simbol & Skala & Referensi \\
\hline \multicolumn{4}{|l|}{ Variable Bebas } \\
\hline \multicolumn{4}{|l|}{ Demografi (X1) } \\
\hline Jenis Kelamin & $\mathrm{X} 1.1$ & Nominal & \multirow[t]{4}{*}{ Alnjadat et al. (2019) } \\
\hline Usia & $\mathrm{X} 1.2$ & Ordinal & \\
\hline Tingkat Pendidikan & $\mathrm{X} 1.3$ & Ordinal & \\
\hline Tingkat Pendapatan & $\mathrm{X} 1.4$ & Ordinal & \\
\hline \multicolumn{4}{|l|}{ Motivasi (X2) } \\
\hline Tujuan utama memakai aplikasi & $\mathrm{X} 2.1$ & Nominal & \multirow[t]{3}{*}{ Alhabash dan Ma (2017) } \\
\hline Keinginan membagikan video & $\mathrm{X} 2.2$ & Ordinal & \\
\hline Alasan membagikan video & $\mathrm{X} 2.3$ & Nominal & \\
\hline \multicolumn{4}{|l|}{ Kategori Konten (X3) } \\
\hline Kategori konten yang paling disukai & $\mathrm{X} 3.1$ & Nominal & \multirow[t]{3}{*}{ Hasan (2017) } \\
\hline Kategori konten yang paling tidak disukai & $\mathrm{X} 3.2$ & Nominal & \\
\hline Tingkat kepuasan terhadap kategori konten & $\mathrm{X} 3.3$ & Ordinal & \\
\hline \multicolumn{4}{|l|}{ Kualitas Layanan (X4) } \\
\hline Fitur Kemudahan merekam video & $\mathrm{X} 4.1$ & Interval & \multirow{7}{*}{$\begin{array}{l}\text { Manalu et al. (2007); } \\
\text { Hasan (2017) }\end{array}$} \\
\hline Desain Magic Emoji & $\mathrm{X} 4.2$ & Interval & \\
\hline Kelengkapan dan kecocokan katalog musik & $\mathrm{X} 4.3$ & Interval & \\
\hline Fitur editor video & $\mathrm{X} 4.4$ & Interval & \\
\hline Kemudahan mengunggah video & $\mathrm{X} 4.5$ & Interval & \\
\hline Kecepatan mengunggah video & $\mathrm{X} 4.6$ & Interval & \\
\hline Proses mengunggah yang stabil & $\mathrm{X} 4.7$ & Interval & \\
\hline \multicolumn{4}{|l|}{ Variable Terikat } \\
\hline \multicolumn{4}{|l|}{ Stickiness (Y) } \\
\hline Tingkat penggunaan aplikasi XYZ & $\mathrm{Y}$ & Interval & Alhabash dan Ma (2017) \\
\hline
\end{tabular}

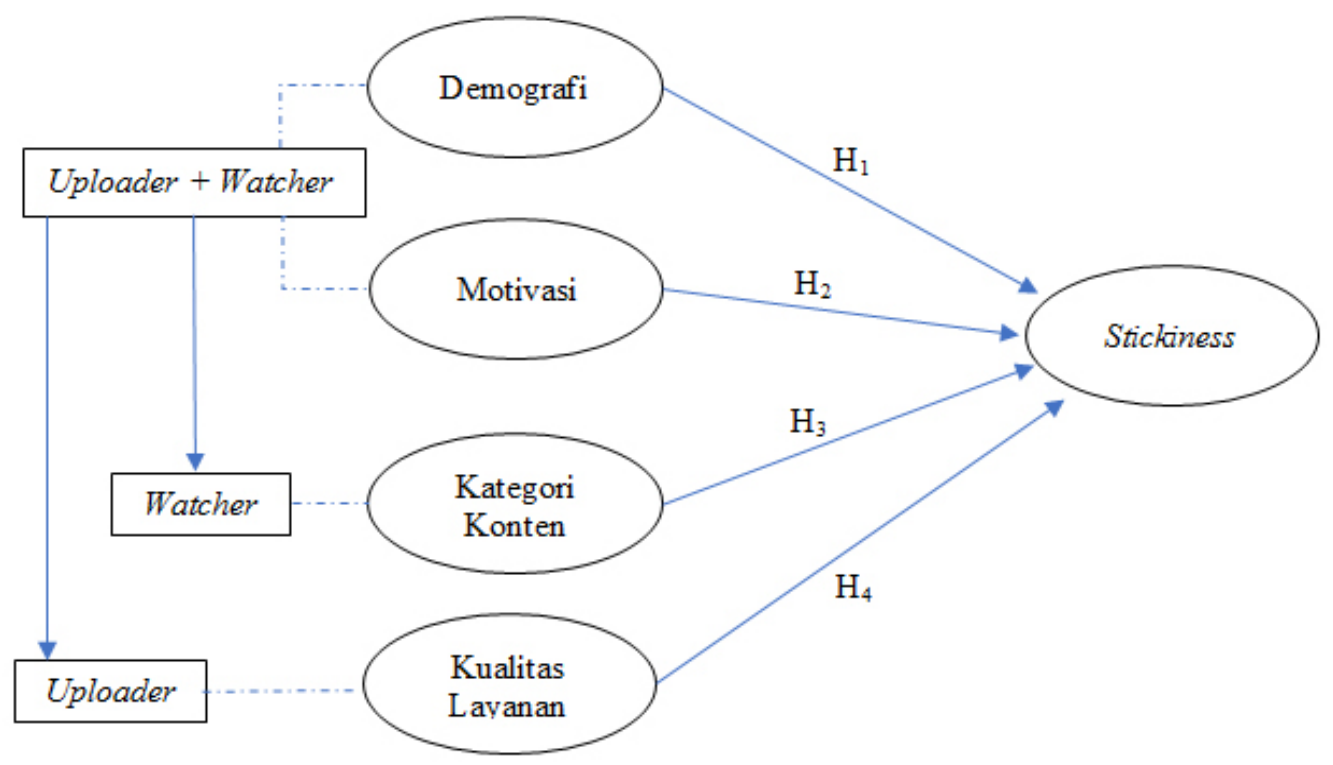

Gambar 1. Kerangka pemikiran penelitian 


\section{HASIL}

\section{Demografi}

Tabel 2 menunjukkan sebaran frekuensi responden variabel demografi untuk kategori uploader, watcher dan total responden. Jenis kelamin lakilaki mendominasi responden sebesar $72,1 \%$. Hal ini menunjukan bahwa aplikasi XYZ lebih disukai oleh pengguna laki-laki daripada wanita. Hasil penelitian sebelumnya menunjukan bahwa laki-laki lebih kecanduan media sosial daripada wanita (Alnjadat et al. 2019). Sebagian besar responden berusia $18-25$ tahun sebesar $42,9 \%$, disusul oleh usia 26 - 30 tahun sebesar 24,2\%. Hal ini sesuai dengan data APJII (2019) bahwa kelompok usia 20 - 24 tahun memiliki penetrasi pengguna internet sebesar $88,5 \%$ dan kelompok usia $25-29$ tahun sebesar $82.7 \%$. Responden memiliki tingkat pendidikan SMA sebesar 57,1\%, disusul S1 sebesar 19,7\% dan SMP sebesar 9,9\%. Adapun untuk tingkat pendapatan, responden memiliki pendapatan bulanan dibawah 2 juta rupiah sebesar 69,3\%. Hal ini menunjukan sebagian besar segmen pengguna aplikasi XYZ berasal dari kelompok sosial ekonomi menengah ke bawah. Sebaran frekuensi karakteristik demografi kategori uploader maupun watcher tidak jauh berbeda dengan total responden.

\section{Motivasi}

Motivasi keseluruhan responden menggunakan aplikasi XYZ adalah menghibur $(61,2 \%)$, mengunggah video $(33,8 \%)$ serta bersosialisasi $(24,6 \%)$. Motivasi keseluruhan responden menggunakan aplikasi XYZ adalah sama dengan motivasi responden kategori uploader maupun watcher, perbedaan hanya terdapat pada komposisi persentasi motivasi yang angkanya relatif tidak jauh berbeda. Motivasi uploader menggunakan aplikasi XYZ adalah menghibur $(60,3 \%)$, menggunggah video (31\%) dan bersosialisasi $(24,7 \%)$. Adapun motivasi watcher menggunakan aplikasi XYZ adalah menghibur (63,8\%), mengunggah video (41,3\%) dan bersosialisasi (24,4\%). Meskipun kategori watcher belum pernah mengunggah video, namun sebesar 41,3\% memiliki motivasi untuk mengunggah video. Hal ini sejalan dengan penilitian Khan (2016) bahwa prediktor terkuat untuk menyukai video adalah motif hiburan, interaksi sosial dan pemberian informasi.
Sebanyak $88,1 \%$ keseluruhan responden berkeinginan untuk membagikan video. Tujuan utama membagikan video $51,7 \%$ untuk menghasilkan uang, 21,9\% untuk berbagi ke teman dan keluarga serta 12,6\% untuk mendapatkan pengikut. Adanya program promosi direct reward berupa koin yang dapat diuangkan untuk video yang berkinerja baik dan program referal berhadiah koin, menjadi penyebab utama pengguna berkeinginan untuk membagikan video.

\section{Kategori Konten yang paling disukai}

Kategori konten dinilai oleh pengguna kategori watcher. Kategori konten yang paling disukai adalah wanita berpenampilan menarik sebesar $47,4 \%$, disusul dengan kategori komedi 30,0\% serta kategori pemandangan sebesar 19,7\%. Dominasi pengguna laki-laki dengan usia muda, menyebabkan preferensi terhadap konten kategori wanita berpenampilan menarik menjadi yang paling tinggi. Hal ini dikarenakan laki-laki muda cenderung menunjukan preferensi gairah seksual yang lebih tinggi terhadap video dengan stimulasi visual secara fisik (Chung et al. 2013).

\section{Kategori Konten yang paling tidak disukai}

Kategori konten yang paling tidak disukai adalah kategori konten fashion dan make up sebesar 29,6\%, disusul kategori gaming sebesar 25,8\% serta kategori dubbing lagu atau acting sebesar 15,0\%. Dominasi pengguna laki-laki pada aplikasi XYZ menyebabkan preferensi pengguna memiliki kecenderungan tidak menyukai konten-konten fashion dan make up yang umumnya sangat erat dengan kegiatan wanita.

\section{Kepuasan terhadap kategori konten yang ada}

Sebanyak $88,3 \%$ responden kategori watcher menyatakan puas terhadap katergori konten yang ada, cukup puas sebanyak 2,3\% dan tidak puas sebesar 9,4\%. Keragaman dan kelengkapan konten merupakan faktor utama para pengguna menyatakan puas (Hasan 2017). Sedangkan responden kategori uploader yang menilai kualitas layanan menunjukkan kepuasan nomor 3 (Netral) untuk setiap kelompok variabel, dengan frekuensi berkisar dari 39,9\% sampai dengan $44,0 \%$. 
Tabel 2. Sebaran karakteristik demografi responden $(\mathrm{N}=797)$

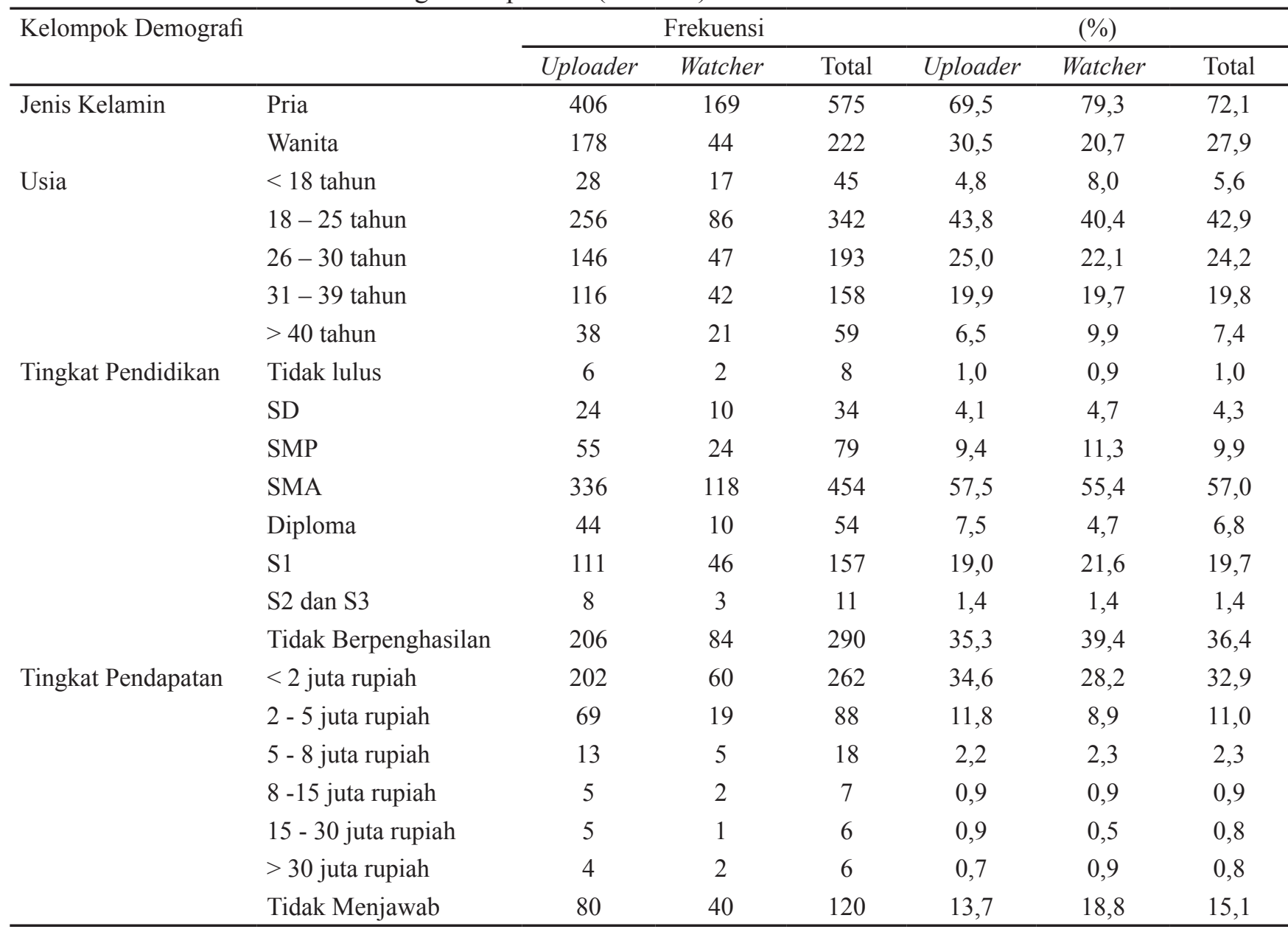

\section{Kualitas Layanan}

Hasil penelitian menunjukan bahwa nilai rata-rata penilaian semua pertanyaan kualitas layanan (hasil transformasi skala Likert ke interval) adalah sebesar 2,9209 (Tabel 3). Nilai ini berada pada interval sikap Netral antara 2,2764 sampai dengan 3,1121, dapat dilihat pada Gambar 2. Semua indikator kualitas layanan berada pada skala interval kepuasan Netral (Tabel 3), dengan nilai yang berkisar dari 2,8013 2,9906. Sehingga dapat disimpulkan bahwa persepsi kualitas layanan dari pengguna aplikasi XYZ, bersikap Netral. Responden belum merasa puas, hal ini dikarenakan keseluruhan layanan belum sesuai dengan yang diharapkan, dirasakan pelanggan atau yang diterimanya (Hannan, 2014). Nilai rata-rata kualitas layanan pada Tabel 3.

\section{Tingkat Penggunaan (Stickiness)}

Sebagian besar pengguna 41,5\% menghabiskan waktu selama 10 - 30 menit di aplikasi XYZ. Sebanyak $21,5 \%$ pengguna menghabiskan waktu selama lebih dari 120 menit setiap harinya. Secara akumulatif sebesar 90,8\% pengguna menghabiskan waktunya menggunakan aplikasi XYZ selama 10 - 30 menit atau lebih. Sedangkan responden kategori uploader 43,5\% menghabiskan waktu selama 10 - 30 menit, sebanyak 21,6\% menghabiskan waktu lebih dari 120 menit, dan secara akumulatif sebesar 92,3\% menghabiskan waktu selama 10 - 30 menit atau lebih. Adapun responden kategori watcher $36,2 \%$ menghabiskan waktu selama 10 - 30 menit, sebanyak 21,1\% menghabiskan waktu lebih dari 120 menit, dan secara akumulatif sebesar $87,9 \%$ menghabiskan waktu selama 10 - 30 menit atau lebih. Secara akumulatif jumlah pengguna uploader lebih banyak menghabiskan waktu $10-30$ menit atau lebih dibandingkan pengguna watcher.

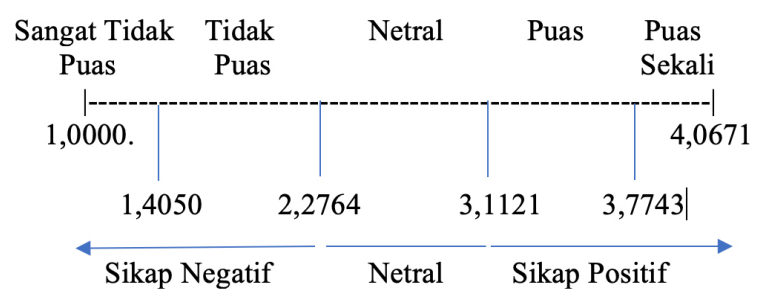

Gambar 2. Skala interval kepuasan kualitas layanan 


\section{Uji Beda Demografi pada Tingkat Penggunaan (H1)}

Perbedaan karakteristik demografi pada keseluruhan responden tidak berbeda nyata terhadap tingkat penggunaan aplikasi XYZ. Hal ini ditunjukan dengan nilai $\mathrm{p}$ hitung hasil uji Kruskal Wallis $>0,05$, yaitu sebesar 0,267 untuk kelompok variabel jenis kelamin, 0,775 untuk kelompok variabel usia, 0,957 untuk kelompok variabel tingkat pendidikan, dan 0,114 untuk kelompok variabel tingkat pendapatan, pada tingkat kepercayaan 95\%. Faktor psikologis diduga lebih berperan. Keputusan pembelian konsumen secara psikologis sangat dipengaruhi oleh motivasi, persepsi, pembelajaran dan memori (Wicaksono et al. 2017).

\section{Uji Beda Motivasi Membagikan Video pada Tingkat Penggunaan (H2)}

HasilUji Kruskal Wallismenunjukkanbahwa, kelompok variabel keinginan membagikan video berbeda nyata pada tingkat penggunaan, ditunjukan dengan nilai $\mathrm{p}$ $=0,001$ (nilai $\mathrm{p} \leq 0,05$ ). Perbedaan secara dominan disebabkan oleh responden yang menjawab Ya yang ditunjukan dengan nilai ranking rataan paling tinggi (Tabel 4) dan memiliki perbedaan paling banyak. Uji Mann Whitney U, menunjukan bahwa responden yang menjawab Ya dan Tidak Yakin $(\mathrm{p}=0,024)$ maupun Ya dan Tidak $(p=0,002)$ dalam kelompok variabel keinginan membagikan video pada tingkat penggunaan hasilnya berbeda nyata, yang ditunjukan dengan nilai $p$ $\leq 0,05$. Terdapat 5 (lima) motivasi menggunakan sosial media yaitu; swafoto (selfie), melakukan cyberwar, belanja daring, personalisasi diri pengguna, dan budaya berbagi (Mulawarman dan Nurfitri, 2017). Motivasi berbagi inilah yang dibuktikan dalam penelitian ini menyebabkan perbedaan pada tingkat penggunaan aplikasi XYZ.

\section{Uji Beda Kategori Konten pada Tingkat Penggunaan (H3)}

Hasil uji Kruskal Wallis menunjukan bahwa kelompok variabel kategori konten yang paling disukai berbeda nyata terhadap tingkat penggunaan dengan nilai $\mathrm{p}=$ 0,019 (nilai $p \leq 0,05$ ). Selanjutnya dilakukan pengujian Mann Whitney U, untuk melihat penyebab perbedaan dalam kelompok variabel kategori konten yang paling disukai.

Hasil uji beda Mann Whitney U (Tabel 5) menunjukan bahwa perbedaan nyata dengan nilaip $\leq 0,05$, disebabkan oleh: 1) Responden yang menyukai kategori konten multiplayer berbeda nyata dengan kuliner, game, bernyanyi, komedi, dubbing, menari dan pemandangan.

2) Responden yang menyukai kategori konten talen/ keahlian berbeda nyata dengan game, bernyanyi dan komedi. 3) Responden yang menyukai kategori konten pemandangan berbeda nyata dengan game. Kategori konten multiplayer bersifat dominan secara positif, karena memiliki ranking rataan tertinggi dan banyak berbeda dengan kategori lainnya. Konten multiplayer adalah video yang pada setiap framenya menampilkan lebih dari dua individu. Penelitian ini menunjukan bahwa keberagaman dan pemilihan konten yang tepat akan memberikan dampak terhadap tingkat intensitas penggunaan aplikasi XYZ.

Tabel 3. Nilai rata-rata kualitas layanan

\begin{tabular}{lccc}
\hline \multicolumn{1}{c}{ Kualitas Layanan } & Terendah & Rata-rata & Tertinggi \\
\hline Kemudahan merekam video & 1 & 2,9746 & 4,1100 \\
Desain magic emoji & 1 & 2,8582 & 4,0100 \\
Kelengkapan dan kecocokan katalog musik & 1 & 2,9276 & 4,1600 \\
Fitur efek mempercantik video & 1 & 2,8013 & 3,9200 \\
Kemudahan mengunggah video & 1 & 2,9906 & 4,1300 \\
Kecepatan mengunggah video & 1 & 2,9365 & 4,0600 \\
Stabilitas mengunggah video & 1 & 2,9578 & 4,0800 \\
Rata-Rata Nilai Kualitas Layanan & & 2,9209 & \\
\hline
\end{tabular}


Tabel 4. Hasil Uji Kruskal Wallis dan Mann Whitney U Motivasi membagikan video pada tingkat penggunaan

\begin{tabular}{|c|c|c|c|c|c|c|c|}
\hline \multirow{2}{*}{ Y } & \multirow{2}{*}{$\mathrm{X} 2.2$} & & \multirow{2}{*}{$\begin{array}{c}\text { Ranking } \\
\text { Rataan }\end{array}$} & $\begin{array}{l}\text { Uji Kruskal } \\
\text { Wallis }\end{array}$ & \multicolumn{3}{|c|}{ Uji Mann Whitney } \\
\hline & & & & $\begin{array}{l}\text { Nilai } p \\
\text { hitung }\end{array}$ & $\begin{array}{l}\text { Nilai } p \\
\text { hitung }\end{array}$ & Ya & $\begin{array}{l}\text { Tidak } \\
\text { Yakin }\end{array}$ \\
\hline \multirow{3}{*}{$\begin{array}{l}\text { Tingkat } \\
\text { Penggunaan }\end{array}$} & Keinginan Membagikan Video & Ya & 409,57 & $0,001 *$ & Ya & & \\
\hline & & Tidak yakin & 337,65 & & Tidak Yakin & $0,024 *$ & \\
\hline & & Tidak & 301,48 & & Tidak & $0,002 *$ & 0,323 \\
\hline
\end{tabular}

* tingkat kepercayaan 95\%

Tabel 5. Hasil Uji Beda Mann Whitney U untuk kelompok variabel kategori konten yang paling disukai pada tingkat penggunaan.

\begin{tabular}{|c|c|c|c|c|c|c|c|c|c|c|c|c|c|}
\hline $\mathrm{Y}$ & $\begin{array}{c}\text { Kategori } \\
\text { Konten Yang } \\
\text { Paling Disukai } \\
\text { (X3.2) }\end{array}$ & $\begin{array}{c}\text { Ranking } \\
\text { Rataan }\end{array}$ & $\mathrm{KL}$ & G & B & $\mathrm{KO}$ & $\mathrm{D}$ & $\mathrm{T}$ & MI & $\mathrm{P}$ & $\mathrm{L}$ & $\mathrm{TL}$ & $\mathrm{BN}$ \\
\hline \multirow{12}{*}{$\begin{array}{l}\text { Tingkat } \\
\text { Penggunaan }\end{array}$} & Kuliner (KL) & 67,00 & & & & & & & & & & & \\
\hline & Game (G) & 84,14 & 0,808 & & & & & & & & & & \\
\hline & Bernyanyi (B) & 95,60 & 0,493 & 0,402 & & & & & & & & & \\
\hline & Komedi (KO) & 95,63 & 0,587 & 0,497 & 0,915 & & & & & & & & \\
\hline & Dubbing (D) & 105,77 & 0,259 & 0,218 & 0,523 & 0,529 & & & & & & & \\
\hline & $\begin{array}{l}\text { Text/slideshow } \\
\text { (T) }\end{array}$ & 117,70 & 0,200 & 0,195 & 0,357 & 0,403 & 0,626 & & & & & & \\
\hline & Menari (MI) & 120,00 & 0,109 & 0,106 & 0,194 & 0,266 & 0,414 & 0,863 & & & & & \\
\hline & $\begin{array}{l}\text { Pemandangan } \\
\text { (P) }\end{array}$ & 123,87 & 0,172 & $0,045^{*}$ & 0,073 & 0,089 & 0,298 & 0,685 & 0,603 & & & & \\
\hline & Liburan (L) & 126,32 & 0,180 & 0,052 & 0,089 & 0,105 & 0,293 & 0,627 & 0,466 & 0,817 & & & \\
\hline & $\begin{array}{l}\text { Talen/Keahlian } \\
\text { (TL) }\end{array}$ & 136,31 & 0,103 & $0,005^{*}$ & $0,010^{*}$ & $0,010^{*}$ & 0,141 & 0,471 & 0,361 & 0,457 & 0,551 & & \\
\hline & Binatang (BN) & 138,25 & 0,134 & 0,088 & 0,144 & 0,183 & 0,267 & 0,524 & 0,405 & 0,670 & 0,775 & 0,938 & \\
\hline & $\begin{array}{l}\text { Multiplayer } \\
\text { (MP) }\end{array}$ & 180,13 & $0,046^{*}$ & $0,006^{*}$ & $0,009^{*}$ & $0,013^{*}$ & $0,023^{*}$ & 0,071 & $0,016^{*}$ & $0,041^{*}$ & 0,054 & 0,151 & 0,155 \\
\hline
\end{tabular}

* tingkat kepercayaan 95\%

\section{Uji Beda Kualitas Layanan pada Tingkat Penggunaan (H4)}

Hasil uji Kruskal Wallis menunjukan bahwa, kemudahan merekam video serta fitur kelengkapan dan kecocokan katalog musik berbeda nyata pada tingkat penggunaan, ditunjukan dengan nilai $\mathrm{p}=0,040$ dan $\mathrm{p}=0,038(\mathrm{p} \leq$ $0,05)$. Perbedaan tingkat kemudahan merekam video pada tingkat penggunaan ditunjukan dengan nilai $\mathrm{p}$ $\leq 0,05$ (Tabel 6), disebabkan oleh adanya perbedaan responden Netral yang berbeda dengan responden Puas $(p=0,005)$, serta responden Sangat Puas yang berbeda dengan responden Puas $(p=0,005)$. Responden Sangat Puas paling dominan menyebabkan perbedaan dengan nilai rataan paling tinggi. Sedangkan pada kelompok variabel kelengkapan dan kecocokan katalog musik, perbedaan disebabkan oleh responden kategori Sangat Puas berbeda dengan responden Puas $(\mathrm{p}=0,017)$, responden Netral berbeda dengan responden Puas ( $\mathrm{p}$ $=0,012)$, dan responden Sangat Tidak Puas berbeda dengan responden Puas $(p=0,024)$. Responden Sangat Tidak Puas paling dominan menyebabkan perbedaan dengan nilai rataan paling tinggi. Hal ini sejalan dengan penelitian sebelumnya bahwa niat penggunaan yang berkelanjutan dipengaruhi oleh persepsi kegunaan, kemudahan penggunaan, dan ketersedian konten yang lengkap dan cocok dengan segmen pengguna (Hasan, 2017). 
Tabel 6. Hasil Uji Kruskal Wallis dan Mann Whitney U untuk kelompok variabel kualitas layanan pada tingkat penggunaan (stickiness)

\begin{tabular}{|c|c|c|c|c|c|c|c|c|c|}
\hline \multirow{2}{*}{$\mathrm{Y}$} & \multirow{2}{*}{$\begin{array}{c}\text { Kualitas Layanan } \\
\text { (X4) }\end{array}$} & \multirow{2}{*}{\multicolumn{2}{|c|}{$\begin{array}{l}\text { Ranking } \\
\text { Rataan }\end{array}$}} & Uji Kruskal & \multicolumn{5}{|c|}{ Uji Mann Whitney U } \\
\hline & & & & Nilai p hitung & Nilai $p$ hitung & $\mathrm{P}$ & $\mathrm{TP}$ & STP & $\mathrm{N}$ \\
\hline \multirow{11}{*}{$\begin{array}{l}\text { Tingkat } \\
\text { Penggunaan }\end{array}$} & \multirow{5}{*}{$\begin{array}{l}\text { Kemudahan } \\
\text { Merekam Video } \\
\text { (X4.1) }\end{array}$} & $\mathrm{P}$ & 224,69 & $0,040^{*}$ & $\mathrm{P}$ & & & & \\
\hline & & $\mathrm{TP}$ & 271,44 & & TP & 0,119 & & & \\
\hline & & STP & 295,95 & & STP & 0,112 & 0,538 & & \\
\hline & & $\mathrm{N}$ & 301,38 & & $\mathrm{~N}$ & $0,005^{*}$ & 0,140 & 0,895 & \\
\hline & & SP & 303,60 & & SP & $0,005^{*}$ & 0,131 & 0,861 & 0,891 \\
\hline & \multirow{6}{*}{$\begin{array}{l}\text { Kelengkapan dan } \\
\text { Kecocokan } \\
\text { Katalog Musik } \\
(\mathrm{X} 4.3)\end{array}$} & & & & Nilai p hitung & $\mathrm{P}$ & ТP & SP & $\mathrm{N}$ \\
\hline & & $\mathrm{P}$ & 242,40 & $0,038^{*}$ & $P$ & & & & \\
\hline & & $\mathrm{TP}$ & 274,31 & & ТP & 0,189 & & & \\
\hline & & SP & 301,32 & & SP & $0,017 *$ & 0,166 & & \\
\hline & & $\mathrm{N}$ & 302,02 & & $\mathrm{~N}$ & $0,012 *$ & 0,129 & 0,961 & \\
\hline & & STP & 330,41 & & STP & $0,024 *$ & 0,096 & 0,299 & 0,299 \\
\hline
\end{tabular}

Keterangan: $\mathrm{STP}=$ Sangat Tidak Puas, $\mathrm{TP}=$ Tidak Puas, $\mathrm{N}=$ Netral, $\mathrm{P}=\mathrm{Puas}$ dan $\mathrm{SP}=$ Sangat Puas

* tingkat kepercayaan $95 \%$

\section{Implikasi Manajerial}

Kegiatan pemasaran aplikasi XYZ dalam menarik pengguna, dapat difokuskan pada segmen lakilaki, usia 18 sampai dengan 30 tahun dengan sosial ekonomi status menengah ke bawah. Pengembangan produk harus difokuskan untuk meningkatkan kualitas layanan, khusunya kemudahan dalam proses merekam dan mengunggah video, serta pengembangan produk elemen, seperti kelengkapan katalog musik yang cocok dengan segmen pengguna. Pengembangan kontenkonten menarik dan menghibur seperti komedi, serta melakukan kerjasama dengan key opinion leader, seperti artis sinetron/film, youtuber, selebgram dan penyanyi. Membuat program-program promosi berhadiah yang melibatkan pengguna dengan orangorang di lingkungan terdekatnya.

\section{KESIMPULAN DAN SARAN}

\section{Kesimpulan}

Sebagian besar pengguna aplikasi XYZ adalah lakilaki, berusia antara 18-30 tahun, memiliki tingkat pendidikan sekolah menengah atas, serta pendapatan di bawah 2 juta rupiah setiap bulannya. Secara keseluruhan intensitas penggunaan aplikasi XYZ sebagian besar selama 10-30 menit atau sebesar
$41,5 \%$ dan secara akumulatif sebesar 90,8\% selama 10-30 menit atau lebih. Karakteristik demografi tidak memberikan perbedaan pada intensitas penggunaan. Adapun motivasi membagikan video berbeda nyata pada tingkat penggunaan. Alasan untuk membagikan video, sebagian besar untuk menghasilkan uang, berbagi kepada teman dan keluarga serta untuk mendapatkan pengikut. Kategori konten yang paling disukai oleh pengguna kategori watcher berbeda nyata pada tingkat penggunaan. Kategori konten yang paling disukai adalah wanita berpenampilan menarik, disusul dengan komedi serta pemandangan. Wacther menyatakan puas terhadap kategori konten yang ada. Pengguna kategori uploader bersikap netral terhadap kualitas layanan. Berdasarkan preferensi uploader menunjukan bahwa kualitas layanan yang berupa kemudahan merekam video serta kelengkapan dan kecocokan katalog musik berbeda nyata pada tingkat penggunaan aplikasi XYZ.

\section{Saran}

Penelitian lanjutan diperlukan untuk melihat lebih dalam faktor strategi marketing yang dilakukan oleh perusahaan dalam hubungannya dengan tingkat penggunaan. Sehingga perusahaan dapat memahami lebih lengkap mengenai proses pengambilan keputusan oleh pengguna dalam hal intensitas menggunakan aplikasi XYZ. 


\section{DAFTAR PUSTAKA}

APJII [Asosiasi Penyelenggara Jasa Internet Indonesia]. 2019. Survey Nasional Penetrasi Pengguna Internet 2018. Jakarta: Asosiasi Penyelenggara Jasa Internet Indonesia.

Ahmad A, Rahman O, Khan MN. 2017. Exploring the role of website quality and hedonism in the formation of e-satisfaction and e-loyalty. Evidence from internet users in India. Journal of Research in Interactive Marketing 11(3):246267.

Alhabash A, Ma M. 2017. A Tale of Four Platform: Motivations and Uses of Facebook, Twitter, Instagram, and Snapchat Among College Students? Social Media + Society. JanuaryMarch 2017: I-13.

Alnjadat R, Hmaidi MM, Samha TE, Kilani MM, Hasswan AM. 2019. Gender variation in social media usage and academic performance among University of Sharjah students. Journal of Taibah University Medical Sciences 14(4):390-394. https://doi.org/10.1016/j.jtumed.2019.05.002.

Manalu ASB, Sumarwan U, Suroso A. 2007. Analisis Faktor-faktor yang Mempengaruhi Kepuasan Pelanggan Online. Jurnal Manajemen \& Agribisnis 4(2): 67-80. https://doi.org/10.17358/ jma.4.2.67-80.

China Internet Watch. 2020. Tiktok competitor Kuaishou announced DAU of over 300 million [internet]. https://www.chinainternetwatch.com/30309/ kuaishou-400m-dau/\#google_vignette. [15 Jun 2020].

Chung WS, Lim SM, Yoo JH, Yoon H. 2013. Gender difference in brain activation to audio-visual sexual stimulation; do women and men experience the same level of arousal in response to the same video clip? International Journal of Impotence Research 25: 138-142.

Dhir A, Torsheim A. 2016. Age and gender differences in photo tagging gratification. Computers in Human Behaviour 63 (2016): 630-638.

Fang, I-Chan, Fang SC. 2016. Factors Affecting Consumer Stickiness to Continue Using Mobile Applications. International Journal of Mobile Communications 14(5): 431-53. https://doi. org/10.1504/IJMC.2016.078720.

Hannan S. 2014. Model Pemasaran Hubungan Pada Jasa Profesi: Studi Empiris Pada Industri Jasa Surveyor Independen Di Indonesia [disertasi]. Bogor. Sekolah Pascasarjana, Institut Pertanian
Bogor.

Hasan VA. 2017. Analisis Fakto-faktor yang Mempengaruhi Willingness to subscribe: Telaah pada Layanan Video On Demand Netflix. Ultima Management 9(1):22-38.

Hsu TH, Tang JW. 2019. Development of hierarchical structure and analytical model of key factors for mobile app stickiness. Journal of Innovation \& Knowledge 5(2020): 68-79. https://doi. org/10.1016/j.jik.2019.01.006.

Jelcic S. 2015. Perceived Service Quality Through Prism of Demographic and Socio-Economic Characteristics of Customers: Hypermarket Stores's Market in The Federation of Bosnia and Herzegovina. DIEM: Dubrovnik International Economic Meeting 2(1):906-912.

Kemp S. 2020. Digital 2020 Global Overview Report [internet]. https://wearesocial.com/ blog/2020/01/digital-2020-3-8-billion-peopleuse-social-media [15 Sep 2020].

Khan ML. 2017. Social media engagement: What motivates user participation and consumption on YouTube? Computers in Human Behavior 66 (2017):236-247.

Khudri MM, Sultana S. 2015. Determinants of service quality and impact of service quality and consumer characteristics on channel selection. British Food Journal 117(8):2078-2097. https:// doi.org/10.1108/BEJ-12-2014-0431.

Kim S, Baek TY, Kim YK, Yoo K. 2016. Factors Affecting Stickiness and Word of Mouth in Mobile Application. Journal of Research in Interactive Marketing 10(3): 177.

Li MH. 2019. Exploring Short Video Application Users's Visit Intention: Applying the StimulusOrganism-Response Model. Asian Social Science Science 15(12):8-19.

Lien CH, Cao Y, Zhou X. 2017. Service Quality, Satisfaction, Stickiness, and Usage Intentions: An Exploratory Evaluation in the Context of WeChat Service. Computers in Human Behaviour 68 (March): 403-410. https://doi.org/10.1016/j. chb.2016.11.061.

Matemba ED, Li G, Maiseli BJ. 2018. Consumers' Stickiness to Mobile Payment Applications: An Empirical Study of WeChat Wallet. Journal of Database Management 29 (3):43-65.

Mulawarman, Nurfitri AD. 2017. Perilaku Pengguna Media Sosial beserta Implikasinya Ditinjau dari Perspektif Psikologi Sosial Terapan. Buletin Psikologi 25(1):36 - 44, https://doi.org/ 
10.22146/buletinpsikologi.22759.

Rahmat ABD, Seminar KB, and Suroso AI. 2019.

Evaluasi Keberhasilan E-Learning Dalam

Perspektif Sistem Informasi (Studi Kasus

Universitas Terbuka). Jurnal Aplikasi Bisnis dan

Manajemen (JABM) 5(3):373-384. https://doi. org/10.17358/jabm.5.3.373.

Sumarwan U. 2011. Perilaku Konsumen, Teori dan Penerapannya dalam Pemasaran. Edisi Kedua. Jakarta: Ghalia Indonesia.

Triola MF. 1992. Elementary Statistic. Fifth Edition.

New York: Addison-Wesley Publishing Company.
Wicaksono AH, Fauzi A, Sunarti. 2017. Pengaruh Faktor Psikologis Konsumen Terhadap Pembelian Impulsif (Survey pada Konsumen yang Melakukan Pembelian Impulsif di Matahari Department Store Matos Malang). Jurnal Administrasi Bisnis (JAB) 46(2):46-53.

$\mathrm{Xu}$ F, Yong-Qi, Xiaotong-Li. 2018. What Affects the User Stickiness of the Mainstream Media Websites in China? Electronic Commerce Research and Applications 29 (2018):124-132. https://doi.org/10.1016/j.elerap.2018.05.001. 